\title{
The Power of Sport to Create Positive Social Change
}

\author{
Richard Lapchick \\ University of Central Florida
}

\section{Introduction}

Good morning. Thank you President Hitt for the warm words. In my opinion, our President, John Hitt, is America's finest university president and it is a pleasure to serve with him. I want to congratulate everyone here for being part of this incredible university and for completing the goal that you set when you came to UCF that you would cross this stage to get your well-earned degrees this morning.

On the stage with me and in the first few rows are some of the best faculty members in the country and it is an honor for me to be one of those faculty members. For me this morning is a special honor because 42 of the graduates here are part of the DeVos Sport Business Management graduate program. You, like everybody else in here, inspire me because I know that you are going to make an incredible impact on this country and the world and we need you now more than ever. I want to start by congratulating the class of 2015.

I am so proud to be your commencement speaker. We have a lot of work to do to make our society whole again and that is what I want to emphasize. But first and foremost I want to congratulate the students who momentarily will become the graduating class, their professors who must be exalting for them, the administrators who must be rejoicing for the success of both the students and their faculty members, for the parents who today exhibit such pride and probably have a secret hope that this is the beginning of the financial independence of their children and an end to the bills (as the father of three college graduates, I can assure you that this is at least partially an illusion), and to salute everybody at this extraordinary university, which is a beacon of opportunity in higher education.

\section{Diversity \& Inclusion}

I thank you for the warm welcome and hope the words that I share this morning will have some meaning for you. I am going to talk largely about diversity and inclusion. At the age of five I looked outside my bedroom window in Yonkers, New York, where I was raised, and saw my father's image swinging from a tree with people picketing underneath. For several years after that I'd pick up the extension phone in our home listening to calls directed at my dad, him not knowing I was listening, and it was racial epithet after racial epithet being hurled at him. As a five-, six-, and seven-year-old boy I didn't understand what it meant except that a lot of people didn't like this man who, for me, was my best friend. Only later would I find out that as the coach of the New York Knicks he had signed the first African-American player in the history of the NBA. There were a lot of people in 1950 who were not happy about that.

In 1960, he wanted me to go to Europe to visit my sister. I wanted to stay home and work on my game. I wanted nothing more than to be an NBA player, but he was a powerful force in my life and he told me that if I went, I would be able to go to Rome where the Olympics were going to be held. On the way to Rome we stopped in Dachau, the Nazi concentration camp. My life was forever changed seeing what people were capable of doing to other people in the name of race, ideology, religion and nationalism. But in Rome, you saw that all of those things the 
Nazis used to divide us did not matter. These were athletes playing at the highest competitive level to reach a goal that they had worked all their lives for and it sent a message to me that sport has the power to bring about positive social change.

Diversity and inclusion can bring perspective. When I was 15 years-old, raised in an almost all-white community in Yonkers, New York, I was recruited by a high school in New York City called Power Memorial. I joined six of the players - five white and one Black - at that high school at a camp the next summer. One of the white players at that camp was dropping the $\mathrm{N}$-word on the black guy all day long for several days until I finally challenged him. The white guy knocked me out. The black guy at the time was known as Lew Alcindor, who later changed his name to Kareem Abdul-Jabbar. He has been a close personal friend of mine for all these years, and as a 15-year-old boy I suddenly had the perspective of an African-American urban youth to show me what racism was doing in our communities, which I might not have seen just being raised in Yonkers.

I also listened to the perspectives of the women in my life. My sister had a tremendous impact on me. I remember as a high school student hearing her cry one night, and when I asked her what was wrong she said she had been named by her fellow students as the best looking and the best athlete. They told her she had to choose one and she wanted to follow in my dad's footsteps. My dad, in addition to coaching the Knicks, was a Basketball Hall of Famer. She was crying because we were 20 years away from Title IX being passed and she knew she couldn't be an athlete. She had to choose best looking and ended up being a successful model, but that was not the path she would have chosen had she had that opportunity.

\section{Activism}

In my adult life, my wife, Ann, has helped me focus on the human rights abuses and continuing lack of opportunity for women, which we make an important part of our discussions at the DeVos program.

I listen to the voices of young people and their needs. Our daughter, Emily, came home as a sophomore from college and started talking about human trafficking. This was 2009 when not many people were talking about human trafficking. I have a $\mathrm{PhD}$ in international race relations and studied the Atlantic Slave Trade in some detail and knew that 10 million Africans ended up in the United States as slaves, 8 million were slaves in Africa and 6 million were slaves in Asia during the 240-year history of the slave trade. Today, as we sit here in this beautiful arena, it is incredibly sad for me to tell you there are 27 million human slaves today, more than at any other time in human history. Not over 240 years, but today, and my daughter has inspired me to get involved in that issue.

I listened to my elders. I was very angry, and I am not an angry person, in the five days after Hurricane Katrina watching what was happening to approximately 100,000 AfricanAmericans inside the Superdome and Convention Center with no help in sight. And then finally CNN put up split-screen images of what FEMA was saying was going on and what was actually going on, and the buses began to come in and bring people out. One of the places they brought them first was to Baton Rouge, and I was lucky enough that Orlando Magic CEO Alex Martins invited me to go down with the Orlando Magic to Baton Rouge to volunteer in the shelter. As I said, I went as an angry person, but one of the seminal moments of my life was standing with Alex and the pastor of a church at the end of the second day. There was a long line of people waiting to speak to an older woman on the side of the church. There were five cots and beds on either side of her and I asked the pastor who she was. He said her name was Ida Johnson. She 
was 106 years-old, and that was five generations of her family sitting on either side of her. So I went up to her knowing that they were all from the Lower $9^{\text {th }}$ Ward where there was not a habitable structure left. To this day I have no idea what I said to Ms. Johnson, but I will never forget what Ms. Johnson said to me. "God is good." That was her perspective with everything having been taken from her life except the family that surrounded her: "God is good."

\section{American Realities}

During the ten minutes that I am going to have to speak to you this morning, this is what would have happened if this was an average ten minutes in our country: 34 students would have dropped out of high school, 11 students would have been victimized by violence, a child under the age of 16 would have been killed by a handgun, 900 children were abused, 129 women or girls were battered, 26 were raped, and 28 were enslaved. During this ten minutes.

It is why I wanted to be here this morning; to help challenge you to continue the work you are doing in your communities if you already are or to pick up the baton if you are not and get involved in those communities.

If you listen to people with diverse backgrounds, you will be able to make better decisions and do the right thing. I have no doubt that if there were more women and people of color in decision-making positions that all of these issues that I have just spoken about would have been addressed a long time ago in a much more serious way rather than some of the leaders that we have addressing this now.

As educated people who are knowledgeable about these issues, you have the opportunity to help young people believe in what they cannot see. You can help them build a floor on the despair that affects so many lives and a roof over the dreams that they have of what they might be able to do with their lives. You can help our children, our community, our nation and the world. There is no doubt that it depends on you because people in despair can be helped by people who care, and I know the UCF community — led by our President, faculty, administrators and especially all of the students - is a community that really cares.

\section{Conclusions}

I come from the world of sport, and one of our gifts in the world of sport is the huddle. We call it the miracle of sport. And I hold this up as an example for us at institutions of higher education, in our religious communities and in corporate America. Think of what happens in the huddle. Where else does it not matter if you're African-American, white, Latino, Native American, Asian American or Arab American? Where else doesn't it matter if you are Protestant, Catholic, Buddhist, Jewish, Hindu or Muslim? Where else doesn't it matter if you are rich or poor, come from a straight family or gay family? If you do not pull together as a team, you cannot win. Can't we bring that as a model for the rest of our society? Imagine what it would be like.

Decades ago I was involved in an ice breaker exercise where the person who was running the exercise asked everybody to think about what they would like written on their tombstone. I thought about it more seriously than most people did that day and what I said when she gave me the turn to respond was that, "He didn't have to be Jewish to fight against anti-Semitism, he didn't have to be a person of color to want to fight against racism, he didn't have to be poor to fight against poverty, he didn't have to be a woman to fight against sexism, he didn't have to be Muslim to fight against Islamophobia, and he didn't have to be gay or lesbian to fight against homophobia. He learned early in his life that we're all a part of the same human fabric." 
I thank you from the bottom of my heart and I hope you know that I am more confident of what will happen in our society because you are going to be leaders of it. A singer named Janis Stanfield said something that I think we can carry with us: "You can't do all the good that the world needs, but the world needs all the good that you can do." Thank you so much. 